\title{
Chromosome 17q12 duplications: further delineation of the range of psychiatric and clinical phenotypes
}

\author{
Kamath $\mathrm{A}^{\mathrm{a}}$, Linden $\mathrm{SC}^{\mathrm{b}, \mathrm{c}}$, Evans $\mathrm{FM}^{\mathrm{b}, \mathrm{c}}$, Hall J $\mathrm{J}^{\mathrm{b}, \mathrm{c}}$, Jose SF${ }^{\mathrm{a}}$, Spillane SA ${ }^{\mathrm{a}}$, Hardie ADR ${ }^{\mathrm{a}}$, \\ Morgan SMa ${ }^{\mathrm{a}}$, Pilz DT ${ }^{\mathrm{a}}$
}

a. Institute of Medical Genetics, All Wales Medical Genetics Service, University Hospital of Wales, Cardiff, UK

b. Neuroscience and Mental Health Research Institute, Cardiff University, Cardiff, UK

c. MRC Centre for Neuropsychiatric Genetics and Genomics, Division of Psychological

Medicine and Clinical Neurosciences, School of Medicine, Cardiff University, Cardiff UK

Correspondence-

Dr Arveen Kamath, MRCPCH,

Institute of Medical Genetics, University Hospital of Wales,

Cardiff- CF14 4XW. UK

Tel- 00442920743976

Fax- 00442920743909

E-mail- arveen.kamath@wales.nhs.uk

Funding Information- Funded by the Wellcome Trust through the DEFINE Wellcome Trust Strategic Award

\begin{abstract}
Copy Number Variants (CNVs) at chromosome 17q12 have been associated with a spectrum of phenotypes. Deletions of 17q12 are well described and associated with maturity onset diabetes of the young type 5 (MODY5) and cystic renal disease (HNF1 $\beta$ ) as well as cognitive impairment and seizures. Duplication of $17 q 12$ is emerging as a new genetic syndrome, associated with learning disability, seizures and behavioural problems. The duplication is often inherited from an apparently unaffected parent. Here we describe a three-generation family with multiple individuals carrying a17q12 microduplication with varying clinical features, consistent with variable penetrance. The proband who inherited a $1.8 \mathrm{Mb}$ interstitial $17 q 12$ duplication from his mother presented with developmental delay, behavioural problems and mild dysmorphism. One of his sisters, his maternal uncle and his maternal grandmother also carry the 17q12 microduplication. Clinical features of the carriers include renal problems, diabetes mellitus, learning difficulties, epilepsy and mental illness. Cognitive abilities range from normal function to moderate impairment (full-scale IQ range: 52-99). In light of recent reports of association of this locus with schizophrenia, we performed a detailed psychiatric assessment and confirmed that one family member has symptoms consistent with a diagnosis of schizophrenia and another has a prodromal syndrome with attenuated positive symptoms of psychosis. This report extends the clinical phenotype associated with the 17q12 microduplication and highlights the phenotypic variability.
\end{abstract}

Key Words- 17q12, copy number variants, cognitive impairment, psychosis, schizophrenia 


\section{Introduction}

Recurrent CNVs, typically deletions and reciprocal duplications, occur through nonallelic homologous recombination (NAHR) mediated by flanking segmental duplications (Rudd etal., 2009). Recent advances in technology and the routine use of array-CGH for detecting small chromosomal copy number changes have enabled detection of several deletion/ duplication syndromes. This technology is effective at detecting copy number variants (CNVs) throughout the genome. The challenge lies in clinical interpretation of the arrayCGH results which is based on bioinformatic analysis of the region involved and determining inheritance of CNVs by parental studies, but crucially involves the detailed phenotyping of the affected families.

Recurrent genomic rearrangements of chromosome 17q12 have been associated with varied clinical phenotypes. Deletions of 17q12 are well described and associated with paediatric renal disease, maturity onset diabetes of the young type 5 (MODY5) as well as cognitive impairment and seizures (Nagamani et al., 2010; Mefford et al., 2007).

The reciprocal duplication of $17 q 12$ is emerging as a new microduplication syndrome with a variable clinical phenotype. Neurological symptoms were the most common features associated with 17q12 duplications, including learning disability, seizures and brain anomalies. Other associated phenotypes observed were behavioural problems, facial dysmorphisms and abnormalities of the kidneys, oesophagus and genitalia (Bierhals et al., 2013). A recent study also showed that $17 q 12$ duplications are a rare cause of familial feverrelated epilepsy syndromes (Hardies et al., 2013).

A recent whole-genome survey of CNVs in patients with schizophrenia has also identified the 17q12 duplication as a risk variant for schizophrenia with an odds ratio of 4.16 (Szatkiewicz et al., 2014). The recent report of a patient with 17q12 duplication and treatment-resistant schizophrenia indicates the need for further studies characterising the range of phenotypes associated with 17q12 duplications (Rogdaki et al., 2016).

Here, we describe a three-generation family with multiple individuals carrying 17q12 microduplication with varying clinical features. Our report adds further clinical data to the variable phenotype of patients with $17 \mathrm{q} 12$ duplications and aims to provide an overview of this condition.

\section{Methods}

\section{A) Patient recruitment and genotyping}

The family was recruited through the identification of a $1.8 \mathrm{Mb}$ interstitial duplication of $17 q 12$ in the proband, who was referred to the All Wales Medical Genetics Service for assessment of his developmental delay. Parental follow-up FISH studies showed the same duplication in his mother. We offered other family members the opportunity to be seen in the genetics clinic. We obtained their detailed clinical history and conducted a physical examination and initiated FISH studies in the extended family members. (Figure 1- Family pedigree). Patients were recruited to the DEFINE (Defining Endophenotypes From Integrated Neuroscience) cohort, for which ethical approval has been obtained from the South East Wales Research Ethics Committee, and provided their written informed consent. All reported 
members of the family also provided their written consent to this report and publication of their photographs.

B) Psychiatric and psychometric assessment

We conducted a detailed psychiatric assessment, including developmental history, substance use history and mental state examination. We supported formal psychiatric diagnoses with appropriate diagnostic instruments. We used the PAS-ADD (Psychiatric Assessment Schedules for Adults with Developmental Disabilities) (Moss et al., 1997) a diagnostic instrument for mental disorders that is also suitable for people with learning difficulties and the Structured Clinical Interview (SCID II) for personality disorders (First et al., 1997). We used the diagnostic information obtained through the psychiatric interview and the PAS-ADD to formulate diagnoses according to the criteria of the DSM5. We also conducted the Structured Interview for Prodromal Syndromes (SIPS) to explore the presence of subclinical or prodromal psychotic symptoms (Miller et al., 2003). We assessed the severity of current psychotic symptoms in maternal uncle (II: 4) with the SAPS and SANS (Scale for the Assessment of Positive Symptoms, Scale for the Assessment of Negative Symptoms) (Andreasen, 1990) IQ was assessed using the Wechsler Abbreviated Scale of Intelligence (WASI), which yields a full-scale intelligence quotient (IQ) and separate scores for the verbal and performance domains (Wechsler, 2011).

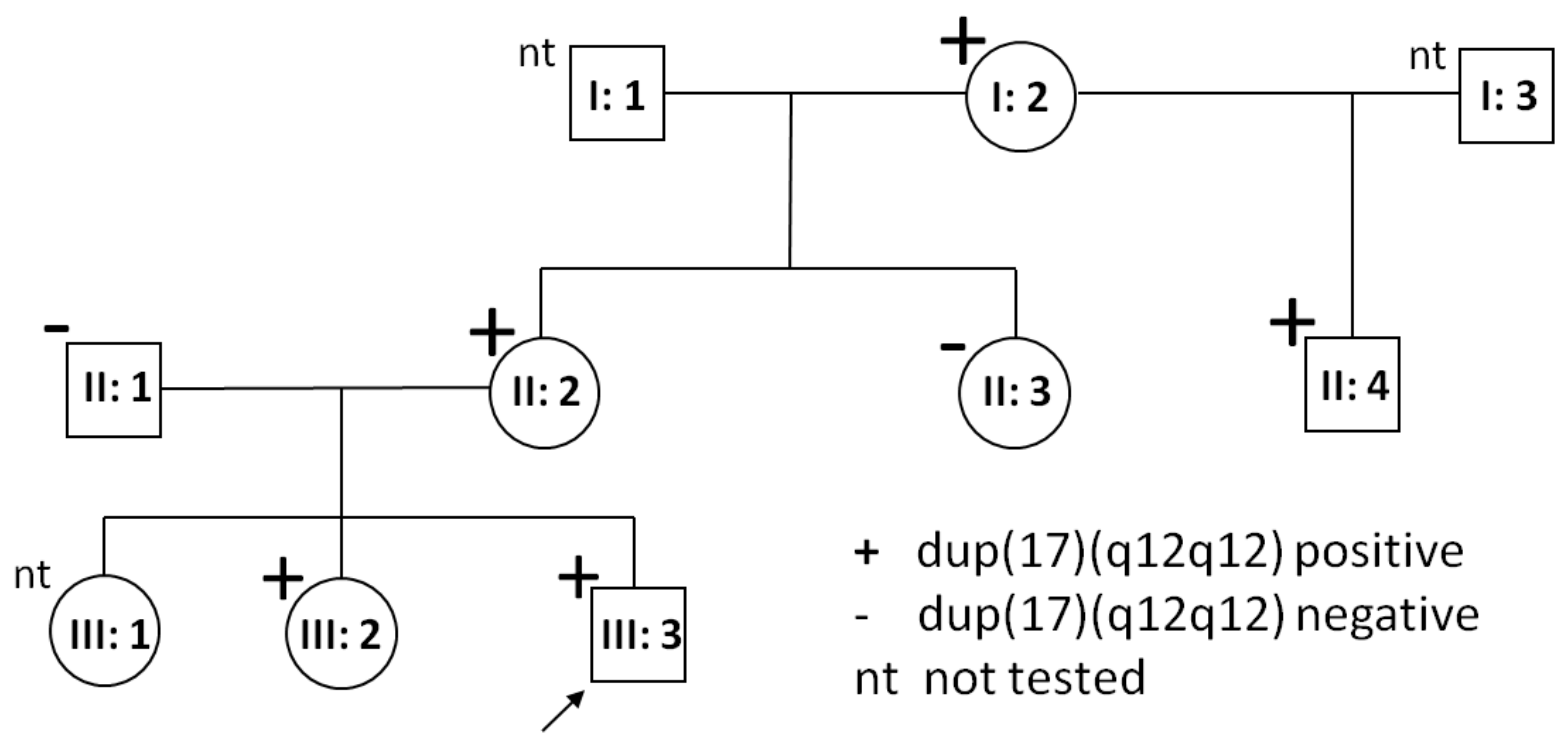

\section{Results}

A) Genotyping

We identified a 1.8Mb interstitial duplication of the long arm of chromosome 17 at q12 (chr17: 34,468,470-36,248,888 according to NCBI Build 37/hg19) (Figure 3a) in the proband and 4 other family members (see Figure 1). We thus confirmed a maternally inherited copy number gain at 17q12 in the proband. This copy number gain was confirmed by FISH using BlueGnome BlueFish probe RP5-986F12 (Figures 3b \& 3c). This region encompassed 29 genes, of which 21 are listed by OMIM (Online Mendelian Inheritance in Man.

http://www.omim.org) : TBC1D3B, CCL3L1, CCL3L3, YWHAEP6, CCL4L1, TBC1D3C, 
CCL3L1, CCL4L2, TBC1D3H, TBC1D3G, RNU6-1192P, RNA5SP439, ZNHIT3, MYO19, PIGW, GGNBP2, DHRS11, MRM1, LHX1, AATF, MIR2909, ACACA, HMGB1P24, C17orf78, TADA2A, DUSP14, SYNRG, DDX52, HNF1B, YWHAEP7. (The OMIM Morbid genes have been underlined in this list with details summarised in the Discussion section).

\section{B) Clinical Reports}

Proband (III: 3 see Figure 1) (Figure 2a \& b)- The index case is a 20 year old man who is the third child of a nonconsanguineous couple and was first seen in the genetics clinic at the age of 7 years. His prenatal period was complicated as his mother developed protein losing nephropathy with subsequent pre-eclampsia. He was born at 36 weeks gestation with a birth weight between $50-75^{\text {th }}$ centile. He was reported to be a content baby but did not breast feed and suffered with constipation. He was noted to have global Developmental Delay (DD) in the first few months of life. He sat at the age of 12 months and walked at the age of 19 months. He had difficulties manipulating small objects, could not skip until 10, only learned to tie his shoelaces at 13 and to ride a two wheeled bike at 20 years of age. His speech was also significantly delayed with the first meaningful word noted at the age of 2 years, and he displayed prominent echolalia. He had difficulties with his coordination whilst growing up and received additional support from a home-visiting educational service for children with additional support needs ('portage help'). He attended a special school and did a life skills course in college. He currently attends day centres five days a week. He lives with his mother and stepfather and has some skills of independent living but needs regular prompting for everyday activities. His mother prepares all his meals and organises all his appointments and activities.

A diagnosis of Attention Deficit Hyperactivity Disorder (ADHD) with autistic tendencies was suggested by the mental health team at the age of 3 . He has been treated with methylphenidate, 10mg twice a day from age 7 until now. He underwent a tonsillectomy at the age of 8 years and is on medications for asthma.

His physical examination revealed brachycephaly with right plagiocephaly, a prominent nose, triangular face and a marked gap between his upper frontal incisors (Fig 2 a). He also had foetal finger pads and fifth finger clinodactyly, bilateral hallux valgus and cubitus valgus. He had a small left parasternal café au lait macule. His weight was between the $9-25^{\text {th }}$ centile and height on the $50^{\text {th }}$ centile, whereas his occipitofrontal circumference (OFC) measured below the $3^{\text {rd }}$ centile.

The initial investigations including a karyotype, testing for Fragile X syndrome, FISH test for Smith Magenis syndrome, mutation analysis of $A R X$ gene and telomere analysis were normal. $\mathrm{CT}$ and MRI scan of the brain and renal ultrasound scan were normal as well.

Detailed psychiatric assessment yielded a diagnosis of Autism Spectrum Disorder (ASD) (DSM-5 code: 299.00) and mild-moderate intellectual disability (IQ total: 52; verbal: 55; performance: 55). The main features of ASD were deficits in social-emotional reciprocity, profound difficulties to develop, maintain, and understand relationships, inappropriate social behaviour (hugging and tickling strangers), inflexible adherence to routines, stereotyped or repetitive motor movements (rocking, clapping hands) and speech (repeats same sentence), highly restricted, fixated interests that are abnormal in intensity or focus (spinning tops; Thomas the Tank, a series of children's books and movies), hyper- reactivity to sensory input 
(he does not like to be touched, does not like certain noises such as balloons popping) as well as unusual interests in sensory aspects of the environment (touching and smelling objects, interest in textures, bright lights). There was no evidence of anxiety disorder (he was reported as loving ‘everything scary', for example balloon rides, thunder and lighting, heights, planes). He mentioned hearing voices of family members calling his name and sometimes felt that others were watching him, but this did not amount to the full clinical picture of a psychotic disorder.

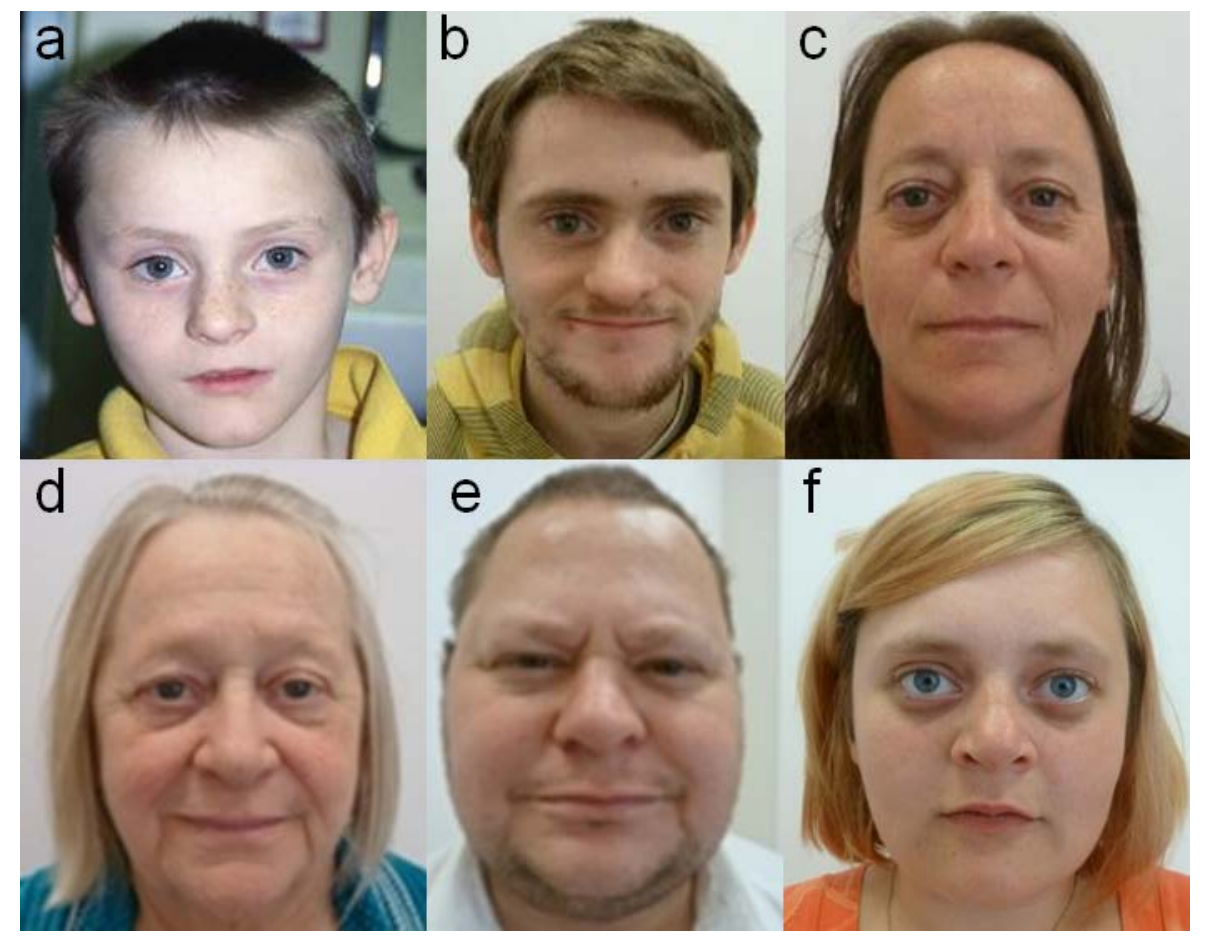

FIGURE 2 Clinical features of the family members. (a and b) Proband (III:3) at age 7 and 19 years, respectively. Note the prominent nose and triangular face. (c) Proband's mother (II:2). (d) Maternal grandmother (I:2). (e) Mother’s half-brother (II:4). (f) Proband’s sister (III:2)
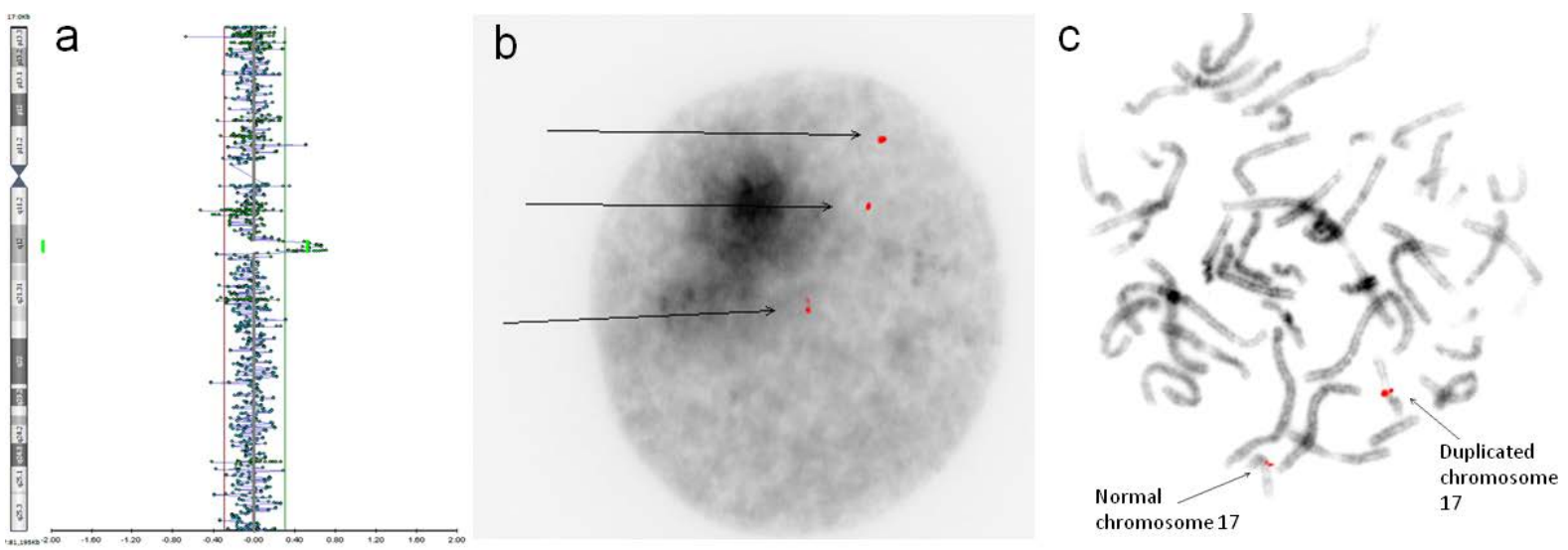

FIGURE 3 (a) An expanded view of the oligonucleotide array-CGH showing the duplicated region in 17q12. (b) Interphase FISH with probe RP5-986F12 revealed three red signals per nucleus, indicative of a duplication (indicated by the arrows). (c) Metaphase FISH with probe RP5-986F12 showing one red signal on the normal chromosome 17 and two red signals located very near to each other indicative of a duplication on the other chromosome 17 (indicated by the arrow) 
Proband's mother (II: 2 see Figure 1) (Figure 2c) - This 46-year old lady had received a diagnosis of focal glomerulonephritis and nephrotic syndrome at the age of 27, with chronic renal impairment requiring dialysis and renal transplantation at the age of 31 . She underwent a tonsillectomy 4 years ago in view of a history of recurrent tonsillitis, a laparoscopic cholecystectomy 6 years ago and Basal Cell Carcinoma (BCC) resection 8 years ago. She has mild pulmonary stenosis confirmed on an echocardiogram and is on treatment for Diabetes Mellitus Type 2 (DM type 2) and Hypertension (HTN).

She had normal developmental milestones (walking at 13 months; first word at 9 months) and no learning difficulties (IQ full-scale: 83; verbal: 78; performance: 90).

She attended mainstream school and left aged 16 without qualifications. She worked as a carer and a cleaner but stopped working when her children were born.

She had difficult teenage years with bullying and physical abuse by her classmates, and as a consequence developed low mood and suicidal ideas. She suffered severe post-partum depression following the birth of her second daughter and also suffered a bout of depression during her dialysis. She did not report any history of psychotic or pre-psychotic symptoms and did not have a current mood disorder. The personality assessment showed some obsessive-compulsive traits.

Maternal grandmother (I: 2 see Figure 1) (Figure 2d) - This lady is 70 years old and had no specific educational problems (IQ total: 99; verbal: 108; performance: 88). She suffered generalised seizures following an accident as a child, which resolved spontaneously in her early teens. She has HTN, DM type 2 and angina (several coronary stents). She had an appendectomy. She suffered a stroke in her late 60s, which has left her with weakness in her right arm. Her renal scan was structurally normal.

Following the breakdown of her marriage during her second pregnancy she went through an episode of depression. She suffers from Acrophobia (DSM-5 code: 309.29) and had Premenstrual Dysphoric Disorder (DSM-5: 625.4) before entering the menopause. During her menopause, she suffered from severe mood swings, aggressive outbursts and dissociative episodes.

Maternal uncle (II: 4 see Figure 1) (Figure 2e) - The 43 year old half-brother of the proband's mother has a history of developmental delay and had experienced behavioural problems since childhood. There were no antenatal problems. He had feeding difficulties in infancy, severe constipation and speech delay, hyperactivity and a poor attention span. His motor development was normal. He had sleeping problems and motor stereotypes (rocking). He had one seizure aged 7 and was on anti-epileptic medication for a few years. He attended a special school for pupils with additional learning needs. He had an operation for testicular torsion aged 12, and an appendectomy aged 15. He had been assessed for specific language impairment, autistic traits and possible psychotic traits. He also has DM type 2, HTN, angina and Irritable Bowel Syndrome (IBS). He is being followed-up for chronic renal impairment, probably secondary to his poorly controlled diabetes. Renal ultrasound scan revealed no abnormality. As reported by his mother, he frequently stops breathing during his sleep; he feels tired during the day and frequently falls asleep and chokes. He has recently been prescribed a CPAP device. 
Psychiatric assessment revealed the presence of schizophrenia (DSM-5 code: 295.90) and specific phobia (DSM-5 code: 300.29). His psychotic symptoms included grandiose delusions, auditory, visual, olfactory and somato-sensory hallucinations and ego-disturbances (for example, he reported feeling other people's emotions and being able to "get into other people's minds”. (SAPS Composite Score: 59; SANS Composite Score: 35). His main phobic symptom was fear of enclosed spaces (claustrophobia). He had a history of a single episode of severe depression with attempted suicide by overdosing on prescription medicines (DSM-5 code: 296.23). His IQ was in the borderline range (IQ total: 76; verbal: 81; performance: 75). He is treated with the antipsychotic drug risperidone and with the antidepressant dothiepine.

Proband's sister (III: 2 see Figure 1) (Figure 2f) - This 27 year old lady was seen in the genetics clinic at the age of 24 years. There were no concerns in the antenatal and postnatal period. She attended a mainstream school with a statement of special educational needs. (IQ total: 79; verbal: 80; performance: 84 ). She had dyslexia, co-ordination and balance difficulties. She developed generalised tonic-clonic seizures at the age of 2 and absence seizures in later life. She has been treated with the anticonvulsant carbamazepine for many years. Because of her seizures she had to stop working as a cleaner 4 years ago. She had plastic surgery on her right ear for cosmetic reasons and to restore symmetry to her face. She has been diagnosed with polycystic ovaries and suffers from migraine and episodic dystonia. MRI scan of the brain and a renal ultrasound scan were normal.

This lady has experienced episodes of low mood and suicidal thoughts since secondary school where she was bullied and suffered physical abuse. She meets diagnostic criteria for Generalised Anxiety Disorder (GAD ; DSM-5 code: 300.02), Social Anxiety Disorder (DSM5 code: 300.23 ), Agoraphobia (DSM-5 code: 300.22), Specific Phobia (Arachnophobia; DSM-5 code: 309.29) and also Avoidant Personality Disorder (DSM-5 code: 301.82). She is currently depressed (Major Depressive Disorder, recurrent; DSM-5 code: 296.32) and has obsessive thoughts. She also suffers from dissociative amnestic episodes. She has attenuated positive symptoms indicating a prodromal syndrome of psychosis (with overvalued ideas, suspiciousness and perceptual abnormalities).

Summary of clinical phenotype (Table I)

Three out of five family members have been diagnosed with DM type 2, two suffered from recurrent tonsillitis requiring a tonsillectomy, one female had gallstones and a cholecystectomy. Three family members have a history of seizures. One female has polycystic ovaries. Only one female had a primary renal problem needing a renal transplantation whereas the other four members had normal renal scans.

The index case has ASD (Autism Spectrum Disorder) and ID (Intellectual Disability), his maternal uncle suffers from schizophrenia and one of his sisters has attenuated positive symptoms of psychosis. Three family members have suffered from episodes of severe to moderate depression. The index case's sister currently fulfils diagnostic criteria for a major depressive episode; she also suffers from agoraphobia, generalised anxiety disorder, social anxiety disorder and avoidant personality disorder.

All female members of the family seem to be sensitive to hormonal changes with PMDD, severe postpartum depression (in two family members) and perimenopausal mood changes (in one family member). 


\section{Discussion}

This three generation family, as well as previously published cases, provides further evidence for pathogenicity of the17q12 duplication. Main features include intellectual disability, psychosis, autistic spectrum disorder, epilepsy, diabetes, renal disorder and mild dysmorphic features. However, there is significant phenotypic variability, and the duplications are commonly found in apparently unaffected parents.

Determining the significance of novel CNVs is challenging. Statistically a deletion or duplication is deemed pathogenic if it is clearly enriched in affected individuals compared with unaffected individuals (Mefford, 2009). The occurrence of a de novo CNV in a symptomatic patient is more than likely to be pathogenic, however, deletions and duplications can no longer be dismissed because they are inherited from an apparently unaffected parent (Mencarelli et al., 2008). Duplication of 17q12 represents a rare copy number variant in the normal population and is slightly enriched in patients with intellectual disability, epilepsy and schizophrenia (Mefford et al., 2007; Szatkiewicz et al., 2014). Factors such as incomplete penetrance, genetic modifiers, epigenetic/environmental factors and difference in size of the deletion/duplication may account for the phenotypic variability of the rearrangement (Mefford et al., 2007; Mencarelli et al., 2008).

Interrogating the DECIPHER database (Firth et al., 2009); we identified more than 100 patients with similar duplications of varying sizes, overlapping with or mapping within the duplication detected in our family at 17q12. Reviewing the 64 patients for whom phenotypic features were available, the majority of the patients were reported as having intellectual disability and dysmorphic features. Autism/behavioural problems and seizures were seen in 15 and 5 patients respectively; psychosis was reported in 1 patient. Multiple renal cysts were documented in 3 patients and obesity in 2 patients. Brain anomalies (cerebellar hemisphere hypoplasia, agenesis of corpus callosum, abnormal Central Nervous System (CNS) myelination), eye problems, microcephaly, hypotonia and short stature were some of the other features documented. Out of the 99 cases, the inheritance was unknown in 53 cases (53.5\%) and in the remaining 46 cases, the duplication was inherited from a parent in 39 of them, majority of the parents were reported as having no health problems.

The comparison of the cases of 17q12 duplication reported in the literature and our family (Table II) reinforces the diverse spectrum of clinical features associated with this condition. The majority of the affected duplication carriers had neurological and psychiatric symptoms including developmental delay, learning difficulty, behavioural problems and seizures. These patients also shared some facial dysmorphisms like bushy eyebrows, epicanthal folds and thin upper lip. Three reported cases of 17q12 duplication were associated with esophageal atresia. One of these cases had other symptoms resembling the VATER association, comprising Vertebral defects, Anal atresia/stenosis, Tracheo-Esophageal fistula, Radial defects and Renal anomalies. The underlying molecular mechanism of esophageal atresia and VATER association is not known. Smigiel et al proposed the role of selected genes such as AATF and $T A D A 2 L$ at the $17 q 12$ region in the development of esophageal atresia (Smigiel et al., 2014).

The 17q12 duplication has been reported previously to be associated with autism and repetitive behaviours (Bierhals et al., 2013; Brandt et al., 2012). Psychotic symptoms have also been described with 17q12 duplication (Nagamani et al., 2010). A Genome wide survey by Szatkiewicz et al for CNVs associated with schizophrenia showed an association of 17q12 duplications with schizophrenia (Szatkiewicz et al., 2014). These findings, in addition to the 
first report of a patient with 17q12 duplication and treatment-resistant schizophrenia described by Rogdaki et al (Rogdaki et al., 2016), confirm the association between 17q12 duplication and schizophrenia.

Deletions in chromosome 17q12, including the $H N F 1 \beta$ gene, are associated with cystic renal disease and maturity onset diabetes of the young (Mefford et al., 2007). A subset of patients with 17q12 duplication reported in the literature as well as one member in our family had renal disease. Deletion and duplication rearrangements may convey phenotypes by various molecular mechanisms, including altering the copy number of dosage sensitive genes, interrupting genes, gene fusion, functional polymorphism and other mechanisms (Lupski and Stankiewicz, 2005). This therefore, raises the possibility, whether renal problems and a propensity to diabetes mellitus type 2 are a part of the 17q12 duplication syndrome.

Overexpression of the genes in the 17q12 region could explain the associated phenotype, and some potential genes have been proposed as candidates for specific phenotypes associated with this rearrangement. 5 genes are known to be of some importance in human disease: CCL3L1 (susceptibility to HIV/AIDS), ACACA (Acetyl-CoenzymeA Carboxylase Alpha) and HNF1B (Non-insulin dependent Diabetes Mellitus, renal cysts and diabetes, renal cell carcinoma), PIGW (Hyperphosphatasia with mental retardation syndrome 5) and ZNHIT3 (PEHO syndrome). The $L H X 1$ gene also maps to this region and is expressed in the human brain, thymus and tonsillar tissue. It encodes a transcriptional regulatory protein involved in the control of differentiation and development of neural and lymphoid cells (Dong et al., 1997). Mouse mutants that lack $L H X 1$ function had a severely compromised head formation (Shawlot and Behringer, 1995). It is hypothesised that the LHX1 gene is dosage-sensitive and may be responsible for some of the neurocognitive (Nagamani et al., 2010) and urogenital phenotypes associated with 17q12 rearrangements. The duplication of the ACACA gene in the 17q12 region has also been implicated in the generation of neurodevelopmental symptoms, including seizures (Hardies et al., 2013). This gene is involved in acetyl-CoA metabolism and its duplication would lead to overutilization of acetyl-CoA which could result in a global energy failure of the brain. However, a causal role has not been validated for any of these genes, and further studies are needed to elucidate candidate genes associated with specific clinical features of the $17 \mathrm{q} 12$ locus. Also, the possibility of a contiguous gene syndrome should be considered.

The full clinical picture associated with $17 q 12$ recurrent duplication is still emerging; nevertheless a number of common clinical features including intellectual disability, developmental delay, behaviour problems and seizures have emerged. Although there are a few shared dysmorphic features noted in these individuals, these features can be variable and there are no consistent features of a clinically recognisable syndrome. Psychiatric and psychological problems have been reported in a subset of individuals affected with 17q12 duplication. However, psychological findings of this condition have been poorly characterised with no detailed descriptions of the psychiatric phenotype in previous publications. We have made detailed psychiatric assessments in our family which further substantiates the association of this duplication with schizophrenia and psychotic symptoms; thereby emphasising the need for close monitoring of psychological issues in affected individuals.

In summary, we add new phenotypic data to the variable spectrum associated with 17q12 duplication. In this three generation family, predominant clinical features were intellectual disability, anxiety and psychotic symptoms, seizures, and mild dysmorphism. Other 
significant associated features were diabetes mellitus and renal impairment, and psychological symptoms associated with menstrual changes in all female members of the family. This report further supports the pathogenicity of 17q12 duplication and also extends the phenotypic spectrum. It also highlights the need to report additional patients with similar duplications to further delineate the different clinical features associated with this region and ultimately unravel the contribution of the different genes of the locus to the clinical phenotype.

Acknowledgements

SCL, FME and JH were supported by the Wellcome Trust Strategic Award Defining Endophenotypes from Integrated Neuroscience (DEFINE) and the MRC Centre for Neuropsychiatric Genetics and Genomics (G0800509).

Conflicts of Interest- The authors have no conflicts of interest to report.

\section{References}

Andreasen NC. 1990. Methods for assessing positive and negative symptoms. Mod Probl Pharmacopsychiatry 24:73-88.

Bierhals T, Maddukuri SB, Kutsche K, Girisha KM. 2013. Expanding the phenotype associated with 17q12 duplication: case report and review of the literature. Am J Med Genet A. $161 \mathrm{~A}(2): 352-359$.

Brandt T, Desai K, Grodberg D, Mehta L, Cohen N, Tryfon A, Kolevzon A, Soorya L, Buxbaum JD, Edelmann L.2012. Complex autism spectrum disorder in a patient with a 17q12 microduplication. Am J Med Genet A. 158A(5):1170-1177.

DECIPHER: Database of Chromosomal Imbalance and Phenotype in Humans using Ensembl Resources. Firth, H.V. et al (2009). Am.J.Hum.Genet 84, 524-533

(DOI: dx.doi.org/10/1016/j.ajhg.2009.03.010)

Dong, W. F., Heng, H. H., Lowsky, R., Xu, Y., DeCoteau, J. F., Shi, X. M., Tsui, L. C., Minden, M. D. 1997. Cloning, expression, and chromosomal localization to 11p12-13 of a human LIM/HOMEOBOX gene, hLim-1. DNA Cell Biol. 16: 671-678.

Faguer S, Chassaing N, Bandin F, Prouheze C, Arveiler B, Rooryck C, Nogier MB, Chauveau D, Calvas P, Decramer S. 2011. A 17q12 chromosomal duplication associated with renal disease and esophageal atresia. Eur J Med Genet. 54(4):e437-440.

First, MB., Gibbon M, Spitzer RL, Williams, JBW, Benjamin LS. 1997. Structured Clinical Interview for DSM-IV Axis II Personality Disorders, (SCID-II). Washington, D.C.: American Psychiatric Press, Inc.,

Hardies K, Weckhuysen S, Peeters E, Holmgren P, Van Esch H, De Jonghe P, Van Paesschen W, Suls A. 2013. Duplications of 17q12 can cause familial fever-related epilepsy syndromes. Neurology. 81:1434-1440.

Lupski JR, Stankiewicz P. 2005. Genomic Disorders: Molecular Mechanisms for Rearrangements and Conveyed Phenotypes. PLoS Genet1(6): e49. 
Mefford HC, Clauin S, Sharp AJ, Moller RS, Ullmann R, Kapur R, Pinkel D, Cooper GM, Ventura M, Ropers HH, Tommerup N, Eichler EE, Bellanne-Chantelot C. 2007. Recurrent reciprocal genomic rearrangements of $17 \mathrm{q} 12$ are associated with renal disease, diabetes, and epilepsy. Am J Hum Genet. 81(5):1057-69.

Mefford HC. 2009. Genotype to phenotype-discovery and characterization of novel genomic disorders in a "genotype-first" era. Genet Med. 11(12):836-842.

Mencarelli, M. A., Katzaki, E., Papa, F. T., Sampieri, K., Caselli, R., Uliana, V., Pollazzon, M., Canitano, R., Mostardini, R., Grosso, S., Longo, I., Ariani, F., Meloni, I., Hayek, J., Balestri, P., Mari, F., Renieri, A. 2008. Private inherited microdeletion/microduplications: implications in clinical practice. Europ. J. Med. Genet. 51: 409-416.

Miller TJ, McGlashan TH, Rosen JL, Cadenhead K, Cannon T, Ventura J, McFarlane W, Perkins DO, Pearlson GD, Woods SW. 2003. Schizophr Bull. 29(4):703-715.

Moss SC, Ibbotson B, Prosser H, Goldberg DP, Patel P, Simpson N. 1997. Validity of the PAS-ADD for detecting psychiatric symptoms in adults with learning disability. Social Psychiatry and Psychiatric Epidemiology. 32(6):344-354.

Nagamani SC, Erez A, Shen J, Li C, Roeder E, Cox S, Karaviti L, Pearson M, Kang SH, Sahoo T, Lalani SR, Stankiewicz P, Sutton VR, CheungSW. 2010. Clinical spectrum associated with recurrent genomic rearrangements in chromosome 17q12. Eur J Hum Genet. 18(3):278-284.

Rogdaki M, Jauhar S, McCutcheon R, Howes O. 2016. Treatment-Resistant Schizophrenia in a Patient With 17q12 Duplication. Biol Psychiatry. 80(4):e19-e20.

Rudd MK, Keene J, Bunke B, Kaminsky EB, Adam MP, Mulle JG, Ledbetter DH, Martin CL. 2009. Segmental duplications mediate novel, clinically relevant chromosome rearrangements. Hum Mol Genet. 18(16): 2957-2962.

Shawlot W, Behringer RR.1995. Requirement for Lim1 in head-organizer function. Nature. 374(6521):425-430.

Smigiel R, Marcelis C, Patkowski D, de Leeuw N, Bednarczyk D, Barg E, Mascianica K, Maria Sasiadek M, Brunner H. 2014. Oesophageal atresia with tracheoesophageal fistula and anal atresia in a patient with a de novo microduplication in 17q12. Eur J Med

Genet. 57(1):40-43.

Szatkiewicz JP, O'Dushlaine C, Chen G, Chambert K, Moran JL, Neale BM, Fromer M, Ruderfer D, Akterin S, Bergen SE, Kähler A, Magnusson PK, Kim Y, Crowley JJ, Rees E, Kirov G, O'Donovan MC, Owen MJ, Walters J, Scolnick E, Sklar P, Purcell S, Hultman CM, McCarroll SA, Sullivan PF.2014. Copy Number Variation in Schizophrenia in Sweden._Mol Psychiatry. 19(7):762-773. 
Wechsler, D. 2011. Wechsler Abbreviated Scale of Intelligence-Second Edition (WASI-II). San Antonio, TX: NCS Pearson.

Table I: Summary of clinical phenotype in our family

\begin{tabular}{|l|l|}
\hline Patient & Phenotype \\
\hline a \&b Proband (III:3) & $\begin{array}{l}\text { Moderate- severe learning difficulties, ADHD, Autistic Spectrum } \\
\text { Disorder }\end{array}$ \\
\hline c Proband's mother (II:2) & $\begin{array}{l}\text { Focal Glomerulonephritis, Nephrotic Syndrome, Renal Transplantation, } \\
\text { Mild Pulmonary Stenosis, DM type 2, Postpartum Depression }\end{array}$ \\
\hline d Maternal grandmother (I:2) & $\begin{array}{l}\text { DM type 2, HTN, Angina, Acrophobia, Premenstrual Dysphoric } \\
\text { Disorder }\end{array}$ \\
\hline e Mother's half-brother (II:4) & DM type 2, HTN, Obesity, Depression, Schizophrenia, Specific Phobia \\
\hline f Proband's sister (III:2) & $\begin{array}{l}\text { Generalised Anxiety Disorder, Social Anxiety Disorder, Agoraphobia, } \\
\text { Arachnophobia, Avoidant Personality Disorder, Depression, attenuated } \\
\text { positive symptoms Epilepsy }\end{array}$ \\
\hline
\end{tabular}


Review of Literature of 17q12 duplication cases: (Table II)

\begin{tabular}{|c|c|c|c|c|c|c|c|}
\hline Reference & Sex & Size & Inheritance & $\begin{array}{l}\text { Neurological } \\
\text { features }\end{array}$ & $\begin{array}{l}\text { Psychiatric } \\
\text { features }\end{array}$ & $\begin{array}{l}\text { Dysmorphic } \\
\text { features }\end{array}$ & Other \\
\hline $\begin{array}{l}\text { This report- } \\
\text { Proband III: } 3\end{array}$ & M & $1.8 \mathrm{Mb}$ & Maternal & $\begin{array}{l}\text { Mild -Mod ID, } \\
\text { ADHD }\end{array}$ & ASD & $\begin{array}{l}\text { Brachycephaly, } \\
\text { prominent nose, } \\
\text { triangular face, } 5^{\text {th }} \\
\text { finger } \\
\text { clinodactyly, } \\
\text { hallux valgus }\end{array}$ & Asthma, Tonsillectomy \\
\hline Proband's mother II: 2 & $\mathrm{~F}$ & $1.8 \mathrm{Mb}$ & Maternal & $x^{2}$ & $\begin{array}{l}\text { Depressive } \\
\text { episodes, } \\
\text { Obsessive- } \\
\text { compulsive traits }\end{array}$ & ------------ & $\begin{array}{l}\text { Glomerulonephritis, } \\
\text { Renal Transplantation, } \\
\text { Tonsillectomy, } \\
\text { Cholecystectomy, BCC } \\
\text { excision, Mild Pulmonary } \\
\text { stenosis, DM type 2, } \\
\text { HTN }\end{array}$ \\
\hline $\begin{array}{l}\text { Maternal grandmother } \\
\text { I:2 }\end{array}$ & $\mathrm{F}$ & $1.8 \mathrm{Mb}$ & Unknown & $x^{2}$ & $\begin{array}{l}\text { Depressive } \\
\text { episodes, } \\
\text { Acrophobia, } \\
\text { Premenstrual } \\
\text { Dysphoric } \\
\text { Disorder }\end{array}$ & --- & $\begin{array}{l}\text { DM type 2, HTN, } \\
\text { Angina }\end{array}$ \\
\hline Maternal uncle II: 4 & M & $1.8 \mathrm{Mb}$ & Maternal & $\begin{array}{l}\text { Borderline ID, } \\
\text { Childhood epilepsy }\end{array}$ & $\begin{array}{l}\text { Schizophrenia, } \\
\text { specific phobia, } \\
\text { depressive episode }\end{array}$ & $---\cdot$ & $\begin{array}{l}\text { DM type 2, HTN,Obesity, } \\
\text { Chronic renal impairment }\end{array}$ \\
\hline Proband's sister III: 2 & $\mathrm{~F}$ & $1.8 \mathrm{Mb}$ & Maternal & $\begin{array}{l}\text { Borderline ID, } \\
\text { Childhood } \\
\text { epilepsy, dyslexia }\end{array}$ & $\begin{array}{l}\text { Generalised } \\
\text { Anxiety Disorder, } \\
\text { Major Depressive } \\
\text { Disorder }\end{array}$ & $\begin{array}{l}\text { Prominent nose, } \\
\text { triangular face }\end{array}$ & $\begin{array}{l}\text { Cosmetic surgery on right } \\
\text { ear to restore symmetry } \\
\text { of face }\end{array}$ \\
\hline
\end{tabular}




\begin{tabular}{|c|c|c|c|c|c|c|c|}
\hline Reference & Sex & Size & Inheritance & $\begin{array}{l}\text { Neurological } \\
\text { features }\end{array}$ & $\begin{array}{l}\text { Psychiatric } \\
\text { features }\end{array}$ & $\begin{array}{l}\text { Dysmorphic } \\
\text { features }\end{array}$ & Other \\
\hline $\begin{array}{l}\text { Mefford et al(2007) } \\
\text { IMR379 }\end{array}$ & $\mathrm{F}$ & $1.5 \mathrm{Mb}$ & Unknown & ID & ---------- & - & --------------- \\
\hline 5812 & M & $1.5 \mathrm{Mb}$ & $\begin{array}{l}\text { Maternal- } \\
\text { (epilepsy) }\end{array}$ & $\begin{array}{l}\text { Mild- mod ID, } \\
\text { Epilepsy }\end{array}$ & -------- & ------------ & Focal cortical dysplasia \\
\hline 6498 & $\mathrm{~F}$ & Complex & $\begin{array}{l}\text { Maternal } \\
\text { (unaffected) }\end{array}$ & $\begin{array}{l}\text { Mild-mod ID, } \\
\text { Epilepsy }\end{array}$ & -------- & ------------ & Focal cortical dysplasia \\
\hline $\begin{array}{l}\text { Mencarelli et al(2008) } \\
\text { Case } 6\end{array}$ & M & $1.8 \mathrm{Mb}$ & $\begin{array}{l}\text { Paternal } \\
\text { (unaffected) }\end{array}$ & Severe ID & ---------- & $\begin{array}{l}\text { Brachydactyly, } 5^{\text {th }} \\
\text { finger clinodactyly }\end{array}$ & $\begin{array}{l}\text { XX sex reversal, Peter's } \\
\text { anomaly, soft palate cleft, } \\
\text { Atrial septal defect, } \\
\text { microphthalmia }\end{array}$ \\
\hline $\begin{array}{l}\text { Nagamani et al(2010) } \\
\text { Patient } 5\end{array}$ & M & $\begin{array}{l}1.06- \\
2.46 \mathrm{Mb}\end{array}$ & Unknown & ----------- & ------- & & $\begin{array}{l}\text { Treacheooesophageal fistula } \\
\text { with oesophageal atresia, } \\
\text { Butterfly vertebra at T9 }\end{array}$ \\
\hline Patient 6 & M & $\begin{array}{l}1.06- \\
2.46 \mathrm{Mb}\end{array}$ & $\begin{array}{l}\text { Maternal (ID- } \\
\text { Patient 7) }\end{array}$ & ID & $\begin{array}{l}\text { Oppositional defiant } \\
\text { behaviour }\end{array}$ & $\begin{array}{l}\text { Synorphys, Mild } \\
\text { syndactyly of } 2 / 3 \\
\text { fingers and toes }\end{array}$ & 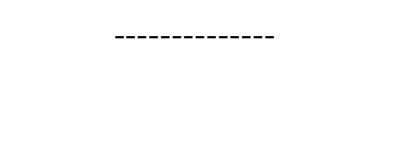 \\
\hline Patient 7 & $\mathrm{~F}$ & $\begin{array}{l}1.06- \\
2.46 \mathrm{Mb}\end{array}$ & Unknown & ID & ---------- & $\begin{array}{l}\text { Mild syndactyly of } \\
\text { 2/3 fingers and toes }\end{array}$ & -------------' \\
\hline Patient 8 & $\mathrm{~F}$ & $\begin{array}{l}1.06- \\
2.46 \mathrm{Mb}\end{array}$ & Unknown & DD & $\begin{array}{l}\text { Behaviour problems, } \\
\text { auditory } \\
\text { hallucinations }\end{array}$ & $\begin{array}{l}\text { Small palpebral } \\
\text { fissures and thin lip }\end{array}$ & $\begin{array}{l}\text { Possible intrauterine drug } \\
\text { and alcohol exposure }\end{array}$ \\
\hline Patient 9 & M & $\begin{array}{l}1.06- \\
2.46 \mathrm{Mb}\end{array}$ & Unknown & DD & --------- & $\begin{array}{l}\text { Triangular face, } \\
\text { small palpebral } \\
\text { fissures, epicanthal } \\
\text { folds, small mouth }\end{array}$ & $\begin{array}{l}\text { Possible intrauterine drug } \\
\text { and alcohol exposure }\end{array}$ \\
\hline
\end{tabular}




\begin{tabular}{|c|c|c|c|c|c|c|c|}
\hline Reference & Sex & Size & Inheritance & $\begin{array}{l}\text { Neurological } \\
\text { features }\end{array}$ & $\begin{array}{l}\text { Psychiatric } \\
\text { features }\end{array}$ & $\begin{array}{l}\text { Dysmorphic } \\
\text { features }\end{array}$ & Other \\
\hline Faguer et al (2011) & $\mathrm{M}$ & $\begin{array}{l}1.42-2.2 \\
\mathrm{Mb}\end{array}$ & $\begin{array}{l}\text { Paternal } \\
\text { (Bilateral) } \\
\text { hypoplastic } \\
\text { kidneys and } \\
\text { renal transplant) }\end{array}$ & ------------ & ------------ & ------------ & $\begin{array}{l}\text { Esophageal atresia type C, } \\
\text { Unilateral Multicystic } \\
\text { hypodysplastic kidney with } \\
\text { megaureter, bladder } \\
\text { divertivulae, ectopic testis, } \\
\text { total epididymis-testis } \\
\text { dissociation with abnormal } \\
\text { epididymis head }\end{array}$ \\
\hline Brandt et al (2011) & $\mathrm{M}$ & $1.4 \mathrm{Mb}$ & De novo & DD, ID & $\begin{array}{l}\text { Behaviour problems, } \\
\text { ASD }\end{array}$ & $\begin{array}{l}\text { Bilateral parietal } \\
\text { bossing, bushy } \\
\text { eyebrows, thick } \\
\text { eyelashes, } \\
\text { epicanthal folds, } \\
\text { hypertelorism, thin } \\
\text { upper lip, } \\
\text { posteriorly rotated } \\
\text { ears, small and } \\
\text { separated teeth }\end{array}$ & $\begin{array}{l}2 \text { Café' au lait macules, } \\
\text { Mildly enlarged ventricles } \\
\text { on Cranial MRI }\end{array}$ \\
\hline Bierhals et al (2013) & $\mathrm{M}$ & $1.4 \mathrm{Mb}$ & $\begin{array}{l}\text { Paternal (type } 2 \\
\text { Diabetes } \\
\text { mellitus) }\end{array}$ & $\begin{array}{l}\text { DD, seizures, } \\
\text { hypotonia }\end{array}$ & $\begin{array}{l}\text { Stereotypical } \\
\text { movements }\end{array}$ & $\begin{array}{l}\text { Microcephaly, } \\
\text { upslanting palpebral } \\
\text { fissures, strabismus, } \\
\text { widely spaced teeth }\end{array}$ & $\begin{array}{l}\text { Joint laxity, brisk tendon } \\
\text { reflexes and extensor } \\
\text { plantar responses, Cranial } \\
\text { MRI- suggested } \\
\text { Periventricular } \\
\text { leukomalacia. }\end{array}$ \\
\hline Smigiel et al (2014) & $\mathrm{M}$ & $1.4 \mathrm{Mb}$ & De novo & $\begin{array}{l}\text { Delayed psychomotor } \\
\text { development, } \\
\text { hypotonia }\end{array}$ & $\begin{array}{l}\text { Normal social } \\
\text { development }\end{array}$ & $\begin{array}{l}\text { Mild facial } \\
\text { dysmorphism, } \\
\text { thumb hypoplasia, } \\
\text { short stature }\end{array}$ & $\begin{array}{l}\text { Oesophageal atresia, } \\
\text { Tracheo-oesophageal } \\
\text { fistula, anal atresia, sacral } \\
\text { bone defect, cryptorchidism }\end{array}$ \\
\hline
\end{tabular}


